\title{
From Civil Society to Civil Servants: Women's \\ Organizations and Critical Elections in Croatia
}

\author{
Jill Irvine
}

\section{University of Oklahoma}

This work examines the role of women's organizations in the 2000 elections in Croatia in an effort to understand when and how they play a significant role in promoting democracy and, in particular, the election of female candidates. Croatia offers a crucial case for the study of gender and democratization because it challenges two significant generalizations from the comparative literature on postcommunist transitions: first, that women's organizations have been more likely to succeed in postcommunist countries where democracy has proceeded the furthest and, in particular, where ethno-nationalist conflict and ideologies are least salient; and, second, that widespread opposition to gender quotas in postcommunist countries prevented their use as a tool for promoting women's equality. What conditions were present that facilitated the effectiveness of women's organizations in Croatia in promoting their goal of electing more women? Four factors are key to explaining their success: the organizational strength and unity of women's organizations; the extent of involvement by international organizations and donors; the perceived central role of women's organizations in democratization; and, finally, the character of their alliances with political parties.

Tn 2000, the first turn-over election took place in Croatia. After almost 1 a decade of semiauthoritarian rule, the center-right Croatian Democratic Union (CDU) lost to a coalition of opposition political parties, supported by a broad spectrum of nongovernmental organizations

An earlier version of this paper was presented at the Thirteenth Berkshire Conference on the History of Women, Scripps College, June 2-5, 2005. I would like to thank Lisa Baldez, Karen Beckwith, Charlie Kenney, Carol Lilly, Andrew Halterman, and three anonymous reviewers for their valuable comments on earlier drafts of this article.

Published by Cambridge University Press 1743-923X/07 \$15.00 for The Women and Politics Research

Section of the American Political Science Association.

(C) The Women and Politics Research Section of the American Political Science Association.

DOI: $10.1017 / \mathrm{S} 1743923 \mathrm{X} 07070055$ 
(NGOs) and other forces of civil society. By all accounts, women's groups and activists were key among them. After the first multiparty elections in 1990, women's representation in the Croatian parliament hovered around $5 \%$, and women's organizations sought to ensure that more women won elections in 2000, as well as to defeat the ruling party. ${ }^{1}$ Recognizing their importance for democratization in Croatia and for ensuring the opposition's victory, international donors extended strong financial support to women's groups. Women's organizations and women's sections of the major trade unions were essential in promoting opposition candidates, fostering fair election practices, getting out the vote, and calling for a change in government. They also pushed for the inclusion of women's issues in the political platforms of opposition parties and for the nomination of female candidates on party lists. Partially as a result of these efforts, the opposition won $68 \%$ of the vote and 95 of 151 seats in the Sabor (parliament). Women roughly tripled their seats to 31 , or $20.5 \%$ of the total. Croatia now had the highest percentage of women in parliament in Eastern Europe.

This article examines the role of women's organizations in the 2000 Croatian elections in order to understand when and how they play a significant role in promoting democracy and, in particular, the election of female candidates. ${ }^{2}$ This study starts from the assumption that successful democratization must also involve the increasing of female political participation and representation (Burns, Schlozman, and Verba 2001; Elshtain 1981; Inglehart and Norris 2003; Pateman 1990). What conditions facilitated the effectiveness of women's organizations in promoting their goal of electing more women? Among the myriad factors identified in the literature on women and democratization, I argue that four are key to explaining their success: the organizational strength and unity of the women's organizations; the extent of involvement by international organizations and donors; the perceived central role of women's organizations in democratization; and, finally, the character of their alliances with political parties.

Croatia offers a crucial case for the study of gender and democratization because it challenges two of the main findings from the comparative literature on postcommunist transitions. The first, a nearly universal conclusion of studies of postcommunist settings, is that they were inhos-

1. Percentage of women elected to the House of Representatives of the Croatian Parliament: 1990: 4.5; 1992: 5.8; 1995: 7.9; 2000: 20.5 .

2. I do not consider all women's groups, but rather those that operated at least partially in a political context. 
pitable to women's activism after the initial phase of regime collapse and that most have remained so despite variations in subsequent political development (Einhorn 1993; Funk and Mueller 1993; Moghadam 1995; Rueschemeyer 1998; Watson 1993). A corollary assumption is that women's organizations have been more likely to succeed over time in those countries where democracy has proceeded the furthest and, in particular, where ethno-nationalist conflicts and ideologies are least salient (Einhorn and Sever 2003; Matland and Montgomery 2003; Waylen 2003). As a country governed by a semiauthoritarian regime engaged in a brutal ethnic war over statehood, Croatia during the 1990s would not appear to fall into this category by any standard of measurement. Yet it was precisely here that women's organizations played a crucial role in electing women candidates, making Croatia the first country in Eastern Europe to reach its pretransition level of female parliamentary representation. The ways in which women's organizations and activists were able to overcome these apparent obstacles to political success are a main focus of this study.

The second generalization called into question by the Croatian case is that the widespread opposition to gender quotas in postcommunist countries prevented their use as a tool for promoting women's equality. Research on gender and transitions has demonstrated that in regions such as Latin America, quotas were crucial to increasing women's parliamentary representation (Friedman 2000; Luciak 2001; Inglehart, Norris, and Welzel 2002; Razavi 2001). Resistance to such quotas in postcommunist settings has been portayed as inimical to improving women's political position there (Jaquette and Wolchik 1998; Matland and Montgomery 2003). Widely associated with the failed gender policies of state socialist regimes, quotas were opposed not only by the public but also by large numbers of women's activists. Such opposition also constituted part of the political landscape in Croatia. Nevertheless, though women's organizations did not achieve their stated goal of introducing statutory quotas, they promoted the adoption of formal and informal quotas within the decision-making bodies and candidate lists of several major political parties. How they achieved this goal is another important part of the story of their success.

Before turning to a discussion of the Croatian case, it is necessary to consider briefly the changing parameters of the political environment that shaped the choices and strategies of women's organizations (Baldez 2003). In Croatia, this environment shifted from a quick collapse of the state socialist regime and founding elections in 1990 to the declaration 
of Croatian independence from Yugoslavia and the outbreak of war in 1991. This war resulted in the occupation of more than one-fourth of Croatian territory until 1995, when peace was officially established through the Dayton Peace Accords. Throughout the 1990s, democratization remained stalled somewhere between electoral and liberal democracy, in what Thomas Carothers (2002) has labeled the phase of "dominant power politics," moving toward full pluralism with the critical turnover elections of 2000. This study examines the interplay of choice and context, illuminating ways in which the changing political environment and institutional context before the 2000 elections shaped and constrained the strategies of women's organizations in increasing their organizational strength, forging a unified political platform based on democratization and the election of women, taking advantage of international support, and finding political allies.

Research for this study was conducted on two trips to Croatia in the summers of 2001 and 2002. ${ }^{3}$ During both trips, I interviewed women's rights activists and parliamentary representatives, as well as human rights activists and scholars. I also interviewed staff members of the National Democratic Institute, the American Center for Labor Solidarity, and the Friedrich-Ebert Stiftung in order to gain a better sense of the involvement of international donors in the 2000 elections. ${ }^{4}$ I collected documents, pamphlets, and other election materials put out by women's organizations, women's sections of the trade unions, and political parties, most of which have not been published. Finally, in the summer of 2003, I presented a preliminary version of this article as a paper at a conference at the Croatia Summer Institute on Race, Gender and

3. The first trip was sponsored by U.S. Agency for International Development (USAID), Democracy and Governance Project. The second trip was funded by the International Research and Exchanges Board. I am grateful to these organizations for their support of my research, though the opinions expressed here are solely my own.

4. I interviewed several NGO activists, including Suzana Jasić, GONG president; Tin Gazivoda, member of the Executive Committee of the Croatian Helsinki Committee for Human Rights; two members of B.a.B.e; and Jill Benderly, director of World Learning STAR Network. I also interviewed two women representatives in the parliament: Dorica Nikolić of the Croatian Social Liberal Party and Vesna Pusić of the Croatian People's Party, as well as Jadranka Cigelj, the head of the women's section of the Croatian Democratic Union. In addition to being briefed by four staff members of U.S. Agency for International Development, I interviewed staff members of international aid organizations, including Karen Gainer, director, National Democratic Institute, and NDI staff member Sarah Gray; Heidi Eterović, American Center for International Labor Solidarity (ACILS) coordinator; and Dr. Nenad Zakošek, Croatian representative of the Ebert Stiftung. I also interviewed several academics and intellectuals who write about contemporary Croatian politics. I identified some interviewees in advance and the remainder through a snowball technique. With the exception of USAID staff, none of the interviewees cited here was promised anonymity. 
Ethnicity; many of the activists about whom I write attended this conference and shared their invaluable insights with me.

\section{THE 2000 ELECTIONS}

The 2000 elections were viewed in Croatia and abroad as a pivotal moment in the attempt to get stalled democratization back on track; removing the CDU from power was considered essential to this task. During its early years in power, the CDU had garnered considerable popular support, as it was perceived as the political party most capable of achieving state-building goals. While many of these goals had been achieved by the second half of the decade, the ruling party faced growing opposition due to its mismanagement of market reforms and its repressive political practices. As the party continued to move toward the right, it increasingly restricted the press, harassed opposition parties and activists, interfered in judicial appointments, and manipulated election laws. The diminishing popularity of the ruling party was indicated by the CDU's relatively poor showing in the 1995 elections to the lower house and the 1997 elections to the upper house of the Sabor. Although public opinion polls indicated a strong lead for opposition parties as much as 18 months before the 2000 elections, there was nevertheless considerable uncertainty about the process and outcome of the voting (IRI Reports 1999). This uncertainty was heightened by the precarious state of President Franjo Tudjman's health and his death at the end of November 1999. ${ }^{5}$

If the theme of the 2000 elections was the declining popularity of the ruling Croatian Democratic Union, their outcome lay in the ability of the opposition to overcome its ineffectiveness and fragmentation. The first sign that opposition forces would finally be able to do so came in the summer of 1998, when the leaders of the Social Democratic Party (SDP) and the Croatian Social Liberal Party (CSLP) announced the formation of an electoral coalition. ${ }^{6}$ After undertaking a program of internal reform in the mid-1990s, the SDP had recovered much of its popular

5. Although some observers worried that the sympathy vote in the aftermath of President Tudjman's death would benefit the CDU, this does not appear to have been the case; the level of support for political parties tracked through public opinion polls during 1999 indicate that voters' level of support for the CDU did not shift significantly in the weeks after Tudjman's death.

6. Ultimately, the opposition entered the election in a $2+4$ electoral coalition with the Croatian Peasant Party, the Istrian Democratic Party, the Liberal Party, and the Croatian People's Party joining together in the second coalition bloc. 
support and, along with its coalition partner the CSLP, it potentially represented a good portion of the electorate. Together, they crafted a campaign message focused on economic corruption, the eroding standard of living, and pensions and other benefits (Carter et al. 2002). The opposition's electoral strategy, along with the waning political fortunes of the CDU, resulted in a decisive defeat for the incumbents. The CDU's share of the vote plummeted from $43 \%$ to $24.5 \%$, while the opposition coalition received over $56.3 \%$ of the vote. Members of the democratic opposition were ecstatic that they had finally been able to break the CDU's stranglehold on political life and to offer a program that could compete effectively with the nationalist vision of the ruling party. This sense was particularly strong among members of women's groups, who felt that they had helped elect the parties now in power along with 31 female candidates.

\section{THE STRENGTH AND UNITY OF WOMEN'S ORGANIZATIONS}

The first factor in explaining the success of women's organizations in promoting the election of more women to political office was their organizational strength and dominant position in civil society. Numerous studies have demonstrated the importance of organizational resources for women's organizations as determined by networks provided through unions, churches, election monitoring organizations, and other actors in civil society, as well as organizational structures and leadership (Baldez 2003; Brand 1998; Fitzsimmons 2000). Studies also confirm the importance of experience accumulated over several electoral cycles (Lindberg 2004). A further key to organizational resources and strength is the ability of women's organizations to overcome internal differences and to promote a shared political agenda, particularly once the unifying force of opposition to the authoritarian regime is gone (Luciak 2001; OkekeIhejirika and Franceschet 2002; Razavi 2001; Vincent 2001). Studies of the Latin American context have most frequently pointed to class conflicts as the major obstacle to unity, as well as such strategic issues as whether and how to engage in the political process. As we shall see, women's organizations in postcommunist settings initially had to overcome the "antipolitics" perspective of civil society (Peto and Szapor 2004). Most importantly, in Croatia as in many other countries, the effectiveness of women's organizations was challenged by ethno-religious cleavages that often eclipsed their goals and concerns (Bunce 2000; Einhorn and Sever 2003; Irvine 1998; Okeke-Ihejirika and Franceschet 2002). 
By the approach of the 2000 elections, women's organizations with a feminist/non-nationalist orientation constituted one of the most dynamic actors in civil society. The emergence and activity of women's organizations during the 1990s can be roughly broken into two periods: the first period from 1991 to 1995 when they focused on providing relief to war victims, and the second period from 1995 to 1999 when some of these organizations began to operate in the electoral and policymaking realms more broadly. During the war years from 1991 to 1995, women's organizations had eschewed the "high politics" of the 1992 and 1993 electoral campaigns, preferring instead to provide care and support to individual victims of the war. Despite this shared strategy of grassroots activism, deep tensions arose among them, and by 1992 they had split into two camps: nationalist and non-nationalist (or patriotic and antipatriotic, according to the Tudjman government's rhetoric) (Knežević, 1994). The nationalist camp included women's organizations formed in response to the war, such as Bedem Ljubavi (Ramparts of Love), Hrvatska Pozadinska Fronta (Behind the Croatian Front), and other avowedly feminist organizations such as Kareta. These women's organizations were determined to counter what they perceived as the pro-Yugoslav stance of many pre-1990 women's organizations; they tended to see Croatia as a victim of Serbian aggression and understood the issue of wartime rape (the deliberate use of rape as part of a policy of ethnic cleansing) within the context of this national victimization (Allen 1996). In the non-nationalist camp were women's organizations from the pre-1990 period, such as the Zagreb Women's Lobby, joined by such new groups as the Center for Women War Victims and Women's Informative Documentary Center, both founded in 1992. These groups were firmly committed to remaining neutral concerning the issue of "war guilt" and understood rape as the result of male behavior during war in which women were the most frequent victims. While the former groups confined their work to the relatively narrow sphere of helping veterans' families after the war ended, and by 2000 were largely defunct, the latter began to turn their attention to the more explicitly political realm. ${ }^{7}$ Convinced that women's rights must be pursued through the promotion of broader social and economic reform, and that this reform was impossible under the Tudjman regime, women's organizations increased their oppositional political activity. Their grass-

7. When I attempted to visit the offices of these groups and interview their leaders in 2001, the offices were closed and the leaders "unavailable" or "retired from public life." 
roots work during the previous several years had afforded these groups the skills, experience, and organizational capacities they needed to play a central role in civil society.

In anticipation of the 1995 parliamentary elections, a number of women's organizations came together at the instigation of a newly formed group, Be.Active.Be.Emancipated (B.a.B.e) to form the Women's Ad Hoc Coalition. B.a.B.e had formed a year earlier with the aim of promoting women's rights within the larger context of human rights, and had already launched a major public initiative to protect abortion rights. Although members of the Ad Hoc Coalition described their activities as a "nonparty" aspect of the election campaign, their organized participation in the election process represented the first step in a gradual transformation among these women's organizations from - in the words of one eminent activist and analyst of the Croatian women's movement-an ethics of care to an ethics of politics (Boric 2003). The aim of the Ad Hoc Coalition was to analyze the ways in which women's issues were represented (or not) in political party programs and in the media, to promote the presence of female candidates on party lists and among their ranks, and to urge women to pay attention to these aspects of the campaign (Dubjević 2002; “Žene u predizbornoj kampanji” 2001). The Coalition's election platform, circulated among the public and political parties, called for greater social, economic, and political equality for women through the formation of a parliamentary body on gender equality (Barilar et al. 2000, 194). The Coalition formed again for the 1997 elections (for the presidency and the upper house of parliament) and again in 1999.

With the formation of B.a.B.e and the Women's Ad Hoc Coalition, women's groups greatly increased their visibility and their ability to operate as effective agents of social and political change. Their organizational strength and resources increased further thanks to the numerous local and regional women's organizations that were now gathered into an effective network encompassing most areas of the country. Building upon their earlier work in petitioning government ministries, publicizing demands, and establishing relationships with some representatives in the Sabor and governmental ministries, women's organizations proved increasingly adept at functioning as effective interest groups within the NGO framework. Through seminars, workshops, and other events, often sponsored by Western organizations such as the National Democratic Institute and American Center for International Labor Solidarity, women's organizations established strong ties with trade unions, politi- 
cal parties, and parliamentary representatives. ${ }^{8}$ Their specifically political activities continued to increase as they engaged in joint public actions with other groups in civil society and responded through petitions and other means to specific decisions of the Croatian government.

An important addition to the network of women's organizations in Croatia in the late 1990s was the growing strength of women's sections in the trade unions, which continued to represent a powerful social and political force. The women's section of the largest trade union, Union of Autonomous Trade Unions of Croatia (UATUC), was particularly active not only in fighting against discrimination on the job and within the UATUC leadership, but also in responding to larger social and political issues. ${ }^{9}$ This work to develop female unionists, at times amid the resistance of the established union leadership, afforded women the skills, visibility, and support to put gender issues on the union agenda and to develop women trade union leaders. Moreover, union advocacy for women's issues had a multiplier effect in the political arena. By the late 1990s, female trade union leaders were participating in seminars, conferences, and other events with representatives of women's organizations, members of political parties, and other activists. Moreover, they had developed a political agenda similar to the one adopted by many women's organizations, in particular their commitment to promoting the election of female candidates. ${ }^{10}$ Members of the UATUC women's section joined with women's organizations and other civil society actors to monitor the 2000 elections. Mindful of the large number of union voters (the four largest trade unions claimed more than half a million members total), political party leaders paid attention when UATUC leaders spoke (Carter et al. 2002).

The Women's Ad Hoc Coalition geared up for the elections once again in the spring of 1999, this time with an explicit focus on the need for further democratization. Due in part to an increase in foreign assistance, the Coalition for the first time had central and regional offices and groups appointed for special tasks. Indeed, according to one organizer, the Coalition's years of experience and better funding allowed "no excuse for dilettantism” (Dubjević 1999). The 28 groups that comprised its mem-

8. Author interview with ACILS representative Heidi Eterović, 8 May 2001.

9. “Conclusions of the International Trade Union Women's Conference, Zagreb, December 3 , 1998" (unpublished leaflet for union members), 2.

10. "Ženska Seksija SSSH July 7, 1999" (unpublished leaflet for union members). See also leaflet from the Union of Autonomous Trade Unions of Croatia N.d., "UATUC Women's Section: Degree of Realization of Women's Trade Union representation in UATUC." 
bership pledged to engage only in nonpartisan election activity aimed at reforming election laws, monitoring political parties and programs, and producing informative election materials; the Coalition would reach the public through forums for women voters, round tables for women political candidates, and "street actions." A full-time volunteer was dispatched to various towns and villages to bring the Coalition's message beyond the major urban centers. Several pamphlets aimed particularly at young women were widely disseminated at election events. Women were urged to vote for a party that would meet their "needs, beliefs and values," to "know who and what they were voting for" and to "carefully monitor" whether their political expectations were being met ("Žene u predizbornoj kampanji” 2001).

A major part of the Coalition's effort was directed at gaining support for its election platform, for which it ultimately gathered 40,000 signatures. The platform, an expanded and reworked version of the Coalition's 1995 platform, was divided into a series of demands relating to employment, social policy, family planning and women's health, domestic violence, education, and women's political participation. Calling for $40 \%$ of women in decision-making bodies, the platform endorsed women's quotas in executive bodies of political parties and candidate lists. It also called for an end to biased or distorted presentation of women in the media and the introduction of "measures to combat sexism, prejudice and stereotypes" (1999 Platform of the Ad Hoc Coalition). Emphasizing the need for a significant social transformation, the document demanded that men "share responsibility in the house and power in the state" ("Žene u predizbornoj kampanji” 2001).

As for reaching consensus on the Ad Hoc Coalition's Election Platform, the item that presented perhaps the most difficulty was gender quotas. The use of gender quotas proved a contentious issue in postcommunist countries, given its perceived association with the failed policies of the old regime. Some women activists appear to have been caught between their personal dislike of quotas, or concern about their unpopularity, and the growing body of evidence from Latin America and elsewhere that quotas provided an effective tool for increasing women's political participation (Novosel 1999). Moreover, the political platform produced at the 1995 Fourth World Conference of Women in Beijing had clearly endorsed such a mechanism. Thus, quotas were included, albeit reluctantly by some, in the Coalition's political platform and became the focus of considerable effort by women's organizations in the period leading up to the 2000 election campaign. 
In addition to its independent election efforts, the Ad Hoc Coalition played a crucial role in Glas (Voice) '99, an organization dedicated to getting out the vote, and GONG (an acronym for Citizens Organized to Monitor Elections). Eventually developing into a countrywide coalition of 148 NGOs, Glas'99 grew out of a decision by human rights, women's, environmental, and student groups to increase popular participation in the 2000 parliamentary and presidential elections. By early 1999, regional coalitions of Glas '99 had launched a hard-hitting, unified marketing campaign that drew on contemporary advertising techniques and targeted women and youth. ${ }^{11}$ Women's organizations in UATUC also linked their work on voter education to Glas '99, of which UATUC was the largest member. Women's organizations and individual activists also worked closely with GONG in mobilizing voters and in educating citizens about the election process, particularly the frequently changing election laws. GONG took a less partisan approach to the elections than Glas '99, and its approval by a wider range of the electorate probably brought greater public acceptance of women's groups as important players in this and other democratizing efforts. ${ }^{12}$

\section{INTERNATIONAL ENVIRONMENT AND ORGANIZATIONS}

The second factor affecting the effectiveness of women's organizations in promoting their electoral goals was the extent of involvement by international organizations and donors. Numerous studies have pointed to the international community's important role in providing financial and moral support and in shaping the discourse and organization of the struggle for women's rights (Baldez 2003; Corrin 2001; Jaquette 2001; Seidman 1999). Strong support from these organizations can substantially strengthen women's ability to play a significant part in elections, although such support can also weaken or discredit women's groups among the general public or cause a fracturing of civil society as groups compete with one another for funds (Bagić 2003; Mendelson and Glenn, 2002; Ottoway and Chung 2002; Richter 2002). It has been argued that the majority of women's activists and organizations in postcommunist countries rejected the international feminist perspective articulated at

11. In a June 1999 public opinion survey prepared by the International Republican Institute, women constituted the largest block of undecided voters at 11\%. "Public Opinion Survey: Political Overview Croatia," International Republican Institute, prepared by Ellen Yount and Nenad Bulat, unpublished report.

12. Author interview with Suzana Jasić, GONG president, 5 May 2002. 
the UN World Conferences on Women and elsewhere, thus depriving them of an important source of support (Baldez 2003; Jaquette and Wolchik, 1998). This appears to have been at least partially the case in Croatia, where some women's organizations criticized international feminist discourse about rape and warfare in the former Yugoslavia (Batinić 2001; Benderly 1997). Nevertheless, as we shall see, women's organizations in Croatia proved receptive to international material support, as well as international discourse concerning women's rights, and used them effectively to promote their political goals.

The changing international environment, along with strong financial support from abroad, significantly strengthened women's organizations in Croatia during the several years preceding the 2000 elections. Strong support for membership in the European Union among the Croatian population meant that there was greater public acceptance of the need to "pay attention" to women's issues, as required by the EU. Moreover, international institutional regimes and norms articulated at the Fourth UN World Conference on Women in Beijing in 1995 strongly reinforced the democratizing work of women's organizations and shaped their activity in three important ways. First, they emphasized the use of quotas as a way of achieving gender parity politically, encouraging women's organizations to adopt this as a political goal. Second, they provided an understanding of women's rights as part of human rights more generally. Thus, women's rights were no longer seen as something that could be dealt with later or somehow marginal to the process but as a central component in the consolidation of democratic norms. The goal of electing more women representatives moved into the mainstream, prompting a shift from, in the words of one activist, "sensationalizing women as victims of war to more institutional support for women in politics." 13 Third, the conference itself and the network of women's human rights organizations it spawned provided essential organizational and moral support for Croatian women's NGOs. For many individual activists, trips abroad to women's congresses and other events gave them a sense of support in the face of the difficult political environment at home (Kesić in Barilar et al. 2000).

Foreign assistance, much of it targeted at women's groups, ensured the organizational survival of women's groups and encouraged them to become more specifically political in their focus. As long as the war was being fought, financial assistance was given to women's organizations in

13. "Skup o statusu žena u središnoj i istočnoj Europi," Kruh i ruže 8 (Fall 1997), 〈htpp:// www.zinfo.hr/hrvatski/stranice/izdavastvo/kruhiruze/kir8/8statuszena.htm〉 (May 2002). 
support of largely humanitarian tasks. After 1995, however, foreign assistance was increasingly directed toward consolidating democracy through the strengthening of civil society and democratically oriented political parties, and toward legal and electoral reform. This assistance peaked before the 2000 elections when the American government, along with the EU, the Open Society Institute, the Friedrich-Ebert Stiftung, and numerous other foundations, increased their funding of women's NGOs, political parties, and other forces in civil society in an effort to bolster the chances of removing President Tudjman and the CDU from power (Carter et al. 2002). Western donors were willing to finance the greater political involvement of women's organizations in the 2000 election campaign to defeat the CDU.

Foreign donors found women's NGOs attractive recipients of aid to promote democratization for several reasons. First, foreign donors viewed the strengthening of civil society as theoretically and practically useful for democratic consolidation. As one of the strongest forces in civil society, women's groups were a natural target for assistance. Indeed, many of these groups had received aid for a number of years as a result of their work with refugees and other victims of the wars in Croatia and BosniaHerzegovina. Moreover, these foreign donors needed local partners with which to work, and women's groups shared, for the most part, their political agenda. As women's groups began to turn to larger issues of public and social policy and to engage in the political process, their interests and those of their Western donors coincided. Both wished to see the repressive government of President Tudjman removed from power and more diverse, democratically oriented representatives elected to the parliament.

At the same time that Western donors encouraged women's organizations to become more involved politically, they also urged other groups to increase the political participation of women. Organizations such as the National Democratic Institute encouraged political parties to recruit women at the local level and to include them in leadership bodies. ${ }^{14}$ Foreign donors expressed particular concern about linking women's NGOs to other sections of the opposition. ${ }^{15}$ In the months leading up to the elections, weekly seminars, training sessions, conferences, and other activities brought together women's organizations and activists with party

14. Author interview with Karen Gainer, director, National Democratic Institute, and Sarah Gray, NDI staff, 8 May 2002. See also NDI Report, October-December 2001.

15. Author interview with ACILS coordinator, Heidi Eterović, 8 May 2001. 
leaders, women members of the parliament, foreign consultants and trainers, and election monitoring groups. And, from a postelection perspective, these efforts paid off. U.S. Agency for International Development, in any case, concluded that money spent on women's organizations prior to the 2000 elections was money well spent indeed (Carter et al. 2002). A postelection study by the women's NGO Infoteka also concluded that the work of the international community in Croatia had gone a long way toward sensitizing political parties to women's issues and political goals (Knežević and Zaborski-Čunović 2000).

Nevertheless, international organizations did not always have a positive impact on the activities of women's organizations. Dealing with international organizations often required a great deal of time and energy, diverting women activists from the more pressing issues at hand. Indeed, according to one human rights activist, during this period relations with international donors and organizations took the lion's share of his organization's time. ${ }^{16}$ Moreover, competition for funding from these organizations created acrimony among NGOs, rather than the cooperation they all believed essential. It also created problems of accountability, as organizations were beholden to foreign donors instead of their women constituents, who, in turn, found it difficult to find a face for their criticism of the NGOs' performance and goals (Bagić 2003).

\section{CENTRALITY OF WOMEN'S ORGANIZATIONS IN PROMOTING DEMOCRATIZATION}

The third factor explaining the success of women's organizations in promoting women candidates in the 2000 elections is their perceived role in pushing for the transition. Previous research has suggested that when women's organizations are seen as central to democratization, they are more likely to be successful in promoting political equality for women (Jaquette and Wolchik 1998; Okeke-Ihejirika and Franceschet 2002; Waylen 2003). Whether they will be able to play such a role depends on a number of factors, including unity, international support, and alliances with political parties. It is also contingent on the environment in which these groups are operating and the balance of political forces and ideologies (Brand 1998). Nationalists, religious fundamentalists, and, to a certain extent, neoliberal ideologies all pose challenges to women's push

16. Author interview with Tin Gazivoda, member of the Executive Committee of the Croatian Helsinki Committee for Human Rights, 7 May 2002. 
for equal rights because such rights may appear peripheral or even inimical to the main goals of these ideologies. As Philomina Okeke-Ihejirika and Susan Franceschet (2002) have pointed out, however, when women's organizations draw on the prevalent political discourse and make genderbased demands from within its parameters, they are more likely to realize their political aims in democratization. In the Croatian case, as we shall see, the struggle for human rights, especially full political rights, became the predominant discourse of the 2000 elections, and women's organizations were central in articulating and promoting it.

In contrast to elections in the early 1990s, when women's organizations ignored the most important issues of the campaign concerning Croatian autonomy and independence, in the 2000 election campaign women's organizations clearly articulated the most important campaign themes of democratic consolidation and economic reform. The Coalition lobbied for election law reforms, observer status for NGOs at polling stations, and the right of Croatian refugees living in Yugoslavia to vote. ${ }^{17}$ It also urged Croatian cooperation with the War Crimes Tribunal at The Hague and the accountability of Croatian officials for wartime massacres. Women's groups had long pressed for solutions to the social problems relating to unemployment and the privatization of pensions and health care. It was precisely these issues that the opposition, at the urging of foreign advisers and based on public opinion polls, adopted as a main campaign theme.

Despite its pledge of nonpartisanship, the Coalition emphasized the need for fundamental change in the Croatian political scene, a thinly disguised call for the defeat of the ruling party. The material produced by the Ad Hoc Coalition often painted the ruling party and its allies in a negative light. For example, one pamphlet produced by the Coalition featured quotations by members of the ruling CDU to the effect that women had no business being in politics; contrasting such statements were ones made by female candidates from opposition political parties (Knežević and Zaborski-Čunović 2000, 44-46). The Coalition urged women to vote for a party that would meet their "needs, beliefs and values," clearly implying that they would be better off voting for the opposition. The thrust of the Coalition's message was unmistakable: that it was time to move forward with the process of democratization and economic reform by electing the opposition and that women's organizations

17. Indeed, according to a study by Infoteka, "the influence [of women's organizations] was disproportionately strong in these elections" (Knežević and Zaborski-Čunović 2000, 10). 
had a crucial role to play in this process. Thus, not only did women's organizations provide the cadre and organizational support for those groups most closely connected with the opposition campaign, but they were also central to the public discourse defining the campaign.

Women's groups faced the challenge of deciding when and how to push for explicitly women's issues. While the platform of the Ad Hoc Coalition focused on women's concerns, most women activists concentrated on getting women candidates elected. They emphasized the link between the election of women and democratization, arguing that women would improve the character of Croatia's political life simply by virtue of being women. In an article in the women's monthly Kruh i ruže published in the summer of 1999, activist Gordana Cerjan-Letić articulated what was a common theme in those pre-election days: Women representatives would help the warring factions in government to communicate better with one another since they were better able to achieve consensus than men, who were more concerned with the struggle for power than with solving social problems. According to this view, given the impact that women would have on the system once elected, it was not necessary to campaign hard for explicitly women's issues. In any case, many women activists felt that the most important task was to remove the conservative and nationalist CDU from power, and the best way to do that was to increase the opposition's ability to mount an effective campaign.

Despite this general sense that women's issues could best be addressed within the larger context of democratization, however, women's organizations did expend considerable energy on attempting to get gender quotas adopted both in the general election laws and by individual political parties. Election laws were revised numerous times in Croatia during the 1990s, usually before elections and to the benefit of the ruling CDU; the 2000 elections were no exception to this pattern (Glaurdić 2003). Members of the Ad Hoc Coalition, in keeping with their election platform, called for mandatory gender quotas to be included in the new election law, thereby ensuring $40 \%$ of female candidates on party lists. Given the high level of resistance to such statutory quotas among policymakers and the public alike, such efforts proved unsuccessful. Moreover, many opposition activists from organizations such as GONG focused on "transparency" issues and perceived the issue of gender quotas as one of secondary importance. Nevertheless, the Coalition agitated on behalf of quotas and other provisions of its election platform, for example, in September 1999 organizing meetings with representatives from all political parties to promote the adoption of internal mechanisms for gender par- 
ity. In response, a number of parties adopted gender quotas or pledged to adhere to the ones they had in place. ${ }^{18}$

\section{ALLIANCES WITH POLITICAL PARTIES}

The final factor affecting the role of women's organizations during the transition is the character of their political alliances, particularly with political parties. Many studies of gender and democratization focus on the character of the emerging political parties and party systems and their relations with women's organizations (Beckwith 2000; Kunovich 2003; Razavi 2001; Waylen 2003). One approach emphasizes the dangers of party dominance during the transition, arguing that it can short-circuit the development of other forms of representation in civil society and the state (Dandavati 2005; Friedman 2000). Lisa Baldez (2003), in contrast, argues that it is precisely their exclusion by political parties and other mainstream actors that provides the catalyst for women to organize independently, a necessary precondition for achieving their political goals. Both the dominance and exclusion models explain important features of the relations between women's groups and political parties in Croatia, particularly during the 1990s. They cannot fully account, however, for the ability of women's groups to forge close alliances with opposition political parties in the 2000 elections while maintaining their organizational autonomy and political objectives. An explanation for this factor must look to the shift in the balance of political forces (Beckwith 2000; Brand 1998), the rise of parties on the left (Luciak 2001; Razavi 2001; Waylen 2003), and the establishment of women's sections in political parties (Glaurdić 2003; Seidman 1999).

An important difference between earlier elections and the elections of 2000 was a shift in the balance of forces that allowed women's organizations to find compatible election allies. Women's organizations established effective alliances with opposition political parties in large part because of their own growing strength, but also because of changes in the opposition itself. During much of the 1990s, the opposition was fractured and dominated by nationalist and conservative political parties. In contrast, in 2000 the opposition to the governing CDU united on a plat-

18. Author interview with Dorica Nikolić, 9 May 2002. While several major political parties, claimed to be using some form of informal gender quotas, the extent to which these exerted any real influence varied widely. According to Sabor Representative Dorica Nikolić, political parties including her own, the Croatian Social Liberal Party, rarely took these gender quotas seriously into account when making personnel decisions. 
form of promoting democratic and economic reform. ${ }^{19}$ Moreover, the opposition political parties were now committed to establishing close links with civil society actors, including women's organizations (Knežević and Zaborski-Čunović 2000). The reemergence of a strong Social Democratic Party, with its history of support for women's issues and candidates, reinforced these links between opposition parties and women's groups. $^{20}$

Opposition political parties were eager to take advantage of partisan activity by women's organizations on their behalf in order to attract female voters. During the second half of the 1990s, the percentage of women among party members climbed steadily in almost every major political party (Novosel 1999, 166-78). Opposition leaders knew they were likely to benefit from this trend as public opinion polls indicated that women were moving to the left and were increasingly likely to vote for opposition parties (Paljković 1997). Moreover, since housewives had previously constituted a core support group for the CDU, opposition leaders hoped to capture this segment of the female vote (Irvine 1998). Women in Croatia had voted throughout the 1990s at relatively high rates; opposition party leaders were, therefore, willing to listen to the women's organizations, which were directing their campaign efforts at mobilizing and politically educating women (Novosel 1999, 216-17). The greater attention political activists paid to attracting women voters fostered effective alliances between women's organizations and political parties.

The ability of women's groups to find political allies increased significantly with the emergence of the SDP as a powerful political actor. During the early part of the 1990s, the SDP was a relatively unimportant political actor, but thereafter its fortunes improved. By the 1997 election, when the SDP's comeback was complete, the party's increasing focus on women was apparent; it was the first parliamentary party to institute internal gender quotas. The SDP's women's section, "Forum for SDP Women," figured visibly in pre-election events at the same time that female SDP candidates held frequent press conferences on issues relating to women in politics. The head of the party and prime minister after the 2000 elections, Ivica Račan, also highlighted women's political equality, calling for the institutionalization of government bodies to promote

19. Author interview with Dr. Nenad Zakošek, Department of Political Science, University of Zagreb, 6 May 2002.

20. Author interview with Dr. Smiljana Leinart Novosel, Department of Political Science, University of Zagreb, 6 May 2002. 
Table 1. Women on candidate lists of political parties in the 2000 election

\begin{tabular}{|c|c|c|c|}
\hline Political Parties & $\begin{array}{l}\text { Number } \\
\text { of Women } \\
\text { on List }\end{array}$ & $\begin{array}{c}\% \text { of } \\
\text { Women } \\
\text { on List }\end{array}$ & $\begin{array}{c}\% \text { of } \\
\text { Women among } \\
\text { First Five } \\
\text { Candidates } \\
\text { on List }\end{array}$ \\
\hline \multicolumn{4}{|l|}{ Social Democratic Party/ } \\
\hline Croatian Social Liberal Party & 41 & 27 & 23 \\
\hline Croatian Democratic Union & 22 & 14 & 20 \\
\hline Coalition of 4 Parties* & 17 & 11 & 10 \\
\hline \multicolumn{4}{|l|}{ Croatian Party of Rights/ } \\
\hline Croatian Christian Democratic Union & 14 & 9 & 9 \\
\hline
\end{tabular}

*Croatian Peasant Party, Liberal Party, Croatian People’s Party, Istrian Democratic Party

women's rights and gender equality and the adoption of the main demands of the Ad Hoc Coalition (Novosel 1999, 177). SDP lists had the highest percentage of female candidates, at 26.6\%. While this was far from the SDP's proclaimed quota of $40 \%$, it nevertheless had a significant impact on the election since the SDP received the highest percentage of votes (see Table 1).

The propensity to pay attention to women's issues went beyond the closest political ally of women's organizations, the SDP. By the late 1990s, all political parties began to pay more attention to women. They established or reinvigorated women's sections, emphasized the need to have women assume positions of leadership in the party and, in some cases, adopted internal gender quotas (Knežević and Zaborski-Čunović 2000, 11-12; Novosel 1999). Even the ruling CDU underwent a transformation in its approach to women's issues. In February 1999, the CDU formed a women's section, Katarina Zrinska, at the same time that the women's service organization, Croatian Women (Hrvatska Žena), composed primarily of CDU women, was given greater attention by party leaders. Moreover, the CDU adopted a gender quota of $25 \%$ female representation in all party bodies and on electoral lists. While much of this activity was mere window dressing - the head of Katarina Zrinska deplored the lack of influence the women's section had in the CDU's internal decision making - it nevertheless reflected greater attention to the task of attracting and retaining female voters. ${ }^{21}$ While it is difficult to establish 
the extent to which it was influenced by women's organizations, it is clear that the Coalition had a significant impact on the propensity of political parties to pay attention to women's political equality.

\section{CONCLUSION}

This article began with the question of how to explain the sharp increase in women's representation in the Croatian parliament in a seemingly inhospitable social, economic, and political, postcommunist environment. How, I asked, were women's organizations able to sustain and even increase their activities throughout almost a decade of stalled democratization? Despite the outbreak of war, the rise of ethno-nationalism, the authoritarian practices of the government, and the popular opposition to "administering" gender equality, they were able to promote the election of female candidates and the adoption of gender quotas by major political parties. They were also central to advancing democratization more generally.

I have argued that four factors best explain the success of women's organizations in Croatia: organizational strength and unity, international support, perceived centrality to the democratic process, and alliances with political parties. First, women's organizations were successful in large part because they were able to build their organizational strength, unify around a political program, and form institutional mechanisms such as the Ad Hoc Coalition, allowing them to coordinate their programs and strategies and to present a clearly identifiable "face" to the public. Second, they took advantage of financial and organizational support from international donors, while drawing upon the human rights discourse of the international women's movement to argue for greater political representation. Indeed, the Croatian case confirms the conclusions of those who point to the importance of this international feminist discourse at the same time that it dispels the notion that East European women rejected it. Third, women's organizations formed the nucleus of the pro-democratization forces, shaping the activities and policies of the opposition. It was their perceived centrality to the process of democratic consolidation that made women's organizations such attractive allies to political parties in the 2000 elections. Finally, women's organizations were in a stronger position to forge effective alliances with political parties and to negotiate the inclusion of female candidates on party lists. Thus, the specifics of the Croatian case powerfully support the conclu- 
sions of scholars studying other transitions regarding the factors that influence women's political success.

Keeping these four explanatory factors in mind, what might the Croatian case tell us about the role of women's organizations in promoting democratization in other settings? The Croatian case may tell us something useful about stalled democratization in postcommunist settings such as Russia, Ukraine, Belarus, Moldova, and Georgia, to name only a few. It may also tell us something about the role of women's organizations in stalled or partial transitions more generally. In these cases, one or more of the essential aspects of democratic consolidation - establishing "stateness," rule of law, political society, and a market economy-are fundamentally, often violently, contested. Democratization, then, also involves periods of hybrid regimes, what David Collier and Steven Levitsky (1997) have called "democracy with adjectives." Several decades after the start of the third wave of democratization, such cases abound in all areas of the world, prompting some scholars to question the usefulness of the democratization paradigm and its assumed trajectory (Bunce 2000; Carothers 2002; Collier and Levitsky 1997; Diamond 2002; O’Donnell 1996; Watson 2000).

While a complete exploration of the applicability of the Croatian case to stalled democratization lies outside the purview of this paper, some preliminary suggestions can be made. The first insight from the Croatian case concerns the ability of women's organizations to overcome the social cleavages and ethno-religious conflicts that often accompany stalled democratization. Despite the initial split in their ranks between nationalists and non-nationalists, a significant portion of Croatian women's organizations were ultimately able to unify around a prodemocracy political program focused on gender equality. An important reason for their success was the organizational strength and experience they gained through the practical work of aiding women war victims. This work allowed them to maintain their organizational autonomy and unity even in the face of governmental repression. Their decision to play an explicitly political role based on articulating the linkages among democratization, human rights, and women's rights was also key. Thus, women's organizations in stalled democratization may do well to draw upon the potentially unifying and strengthening aspects of practical relief and reconstruction work, not, however, eschewing the necessity for direct political engagement.

The Croatian case also suggests how important it is for women's organizations to take advantage of international support. International in- 
volvement is likely to be more extensive and prolonged in the cases of stalled or violently contested democratization. These international actors have usually paid close attention to women's political rights (Kosovo), though not always vigorously (Afghanistan). The bad news is that they can fracture the unity of women's organizations, siphon off valuable energy into grant writing and competition for funds, redefine the missions of these organizations, reduce accountability, and underutilize local personnel. But in the Croatian case, these drawbacks appear to have been counterbalanced or outweighed, at least in the short run, by the beneficial impact of international aid and involvement. Not only did international donors provide financial support to keep afloat women's organizations, but they also encouraged these organizations to play an explicitly political role, helped link them to other sectors of civil society such as women's sections of trade unions and political parties, and promoted the understanding of gender equality as part of democratization more generally.

The international environment proved crucial in another way, namely, by enhancing the ability of women's organizations to shape the discourse of democratization to include women's rights as human rights. Drawing upon such discourse can help organizations to place their activity within the mainstream of the democratizing process and even to shape the discourse and decisions of the democratic opposition. Moreover, human rights discourse may be particularly relevant in settings of stalled democratization, such as Croatia, where the population has endured war and human rights violations. Indeed, it is perhaps precisely in cases of stalled democratization that international feminist discourse concerning women's rights as human rights has the greatest impact. When women's rights become linked to the powerful popular desire for democratization as a means of defending human rights, women's groups have a potent discursive tool at their disposal.

This leads to the third lesson suggested by the Croatian case: By playing a pivotal role in democratization, women's organizations can more effectively promote the election of women. It was their ability to articulate and shape the most important themes of the critical elections of 2000 - consolidation of democracy, protection of human rights (including minority and women's rights), and social justice-combined with their organizational strength and weight in civil society, that caused women's organizations to be seen among the democratic opposition as a, perhaps even the, most important force in civil society. Once the process of peace and reconciliation had begun, women's organizations moved 
quickly to the center of civil society, in part because they were perceived as the actors most likely to promote nonsectarian values essential to further democratization. Thus, in cases of stalled democratization, women's organizations may be particularly well positioned to promote the themes of peace, reconciliation, and democratic consolidation.

The final lesson to be learned from the Croatian case is the importance of establishing links with political parties. After all, it is ultimately the political parties that will determine how many women candidates will be fielded and their position on party lists. In cases of stalled democratization, political parties are often weak, fractured, repressed, and fighting for political survival; democratization may require that opposition parties expend extraordinary efforts to cooperate in overcoming the regime's or ruling party's advantage (Carothers 2002). Of course, political parties must overcome their own differences and be sufficiently strong to effectively contest elections, a process that took almost a decade in Croatia, but they must also look for allies from civil society to bolster their strength. When the other three conditions I have outlined here obtain, women's organizations are likely to be foremost among those allies. As such, they will be in a stronger position to negotiate the inclusion of female candidates on party lists. This is particularly the case if the oppositional alliance is dominated by parties on the left that have historically been more receptive to women's political demands for equal representation. It was precisely these factors that allowed women's organizations in Croatia to succeed in persuading political parties to adopt formal or informal quotas and to pay attention to the inclusion of women on the candidate lists. The results proved definitely that women's organizations in postcommunist settings are as capable of promoting women's political equality as their counterparts elsewhere in the world.

\section{REFERENCES}

Allen, Beverly. 1996. Rape Warfare: The Hidden Genocide in Bosnia-Herzegovina and Croatia. Minneapolis: University of Minnesota Press.

Bagić, Aida. 2003. "Women's Organizing in Post Yugoslav Countries: Talking about Donnors." Paper presented at the Conference on Comparative Perspectives on Gender, Race, Ethnicity and Nation in Post-Socialist Societies and the United States. Zagreb and Poreč, Croatia, June 1-8.

Baldez, Lisa. 2003. "Women's Movements and Democratic Transition in Chile, Brazil, East Germany, and Poland." Comparative Politics 35 (3): 253-73.

Barilar, Vesna and Sanja Kajinić, Biljana Kašić, Nataša Lalić, Jasminka Pešut, and Andreja Zeljak, eds. 2000. Aktivistkinje kako 'opismenitit' teoriju. Zagreb: Centar za ženske studije. 
Batinić, Jelena. 2001. "Feminism, Nationalism, and War: The Yugoslav Case in Feminist Texts.” Journal of International Women's Studies 3 (1): 2-23.

Beckwith, Karen. 2000. "Beyond Compare? Women's Movements in Comparative Perspective." European Journal of Political Research 37 (4): 431-68.

Benderly, Jill. 1997. "Feminist Movements in Yugoslavia 197-1992.” In State-Society Relations in Yugoslavia 1945-1992, ed. Melissa Bokovoy, Jill Irvine, and Carol Lilly. New York: St. Martin's, 183-210.

Borić, Rada. 2003. "Women's Interests in Croatia." Paper presented at the Conference on Comparative Perspectives on Gender, Race, Ethnicity and Nation in Post-Socialist Societies and the United States. Zagreb and Poreč, Croatia, June 1-8.

Brand, Laurie A. 1998. Women, the State and Political Liberalization: Middle Eastern and North African Experiences. New York: Columbia University Press.

Bunce, Valerie. 2000. "Comparative Democratization: Big and Bounded Generalizations." Comparative Political Studies, 33 (6/7): 703-34.

Burns, Nancy, Kay Lehman Schlozman, and Sidney Verba. 2001. The Private Roots of Public Actions: Gender, Equality and Political Participation. Cambridge, MA: Harvard University Press.

Carothers, Thomas. 2002. “The End of the Transition Paradigm.” Journal of Democracy $13(1): 5-21$.

Carter, Lynn, Jill Irvine, Eugene Lin, Bruce Kay, and Ann Phillips. 2002. "USAID/ Croatia Democracy and Governance Activities Impact on Political Change." Unpublished report for USAID/Washington.

Collier, David, and Steven Levitsky. 1997. "Democracy with Adjectives: Conceptual Innovation in Comparative Research." World Politics 49 (3): 430-51.

“Conclusions of the International Trade Union Women's Conference, Zagreb, December 3, 1998.” 1998. Unpublished leaflet for union members, Zagreb.

Corrin, Chris. 2001. "Post-Conflict Reconstruction and Gender Analysis in Kosova." International Feminist Journal of Politics 3 (1): 78-98.

Dandavati, Annie G. 2005. Engendering Democracy in Chile. New York: Peter Lang Press.

Diamond, Larry. 2002. "Elections without Democracy: Thinking about Hybrid Regimes." Journal of Democracy 13 (2): 21-35.

Dubjević, Maja. 1999. "Preparing for the 2000 Elections.” Bread and Roses 11 (Spring/ Summer 1999). (http://www.zinfo.hr/engleski/pages/publishing/breadandroses/issues. htm $\rangle$ (May 2003).

Dubjević, Maja. 2002. “Ženska politika za vrijeme i nakon Tudjmana ili kako se tvrdokornost partijarhat očituje u Hrvatskom drustvu." Kruh i ruže 17: 31-40.

Einhorn, Barbara. 1993. Cinderella Goes to Market Citizenship: Gender and Women's Movements in East Central Europe. London: Verso.

Einhorn, Barbara, and Charlotte Sever. 2003. "Gender and Civil Society in Central and Eastern Europe." International Feminist Journal of Politics 5 (2): 163-90.

Elshtain, Jean Bethke. 1992. Public Man, Private Women: Women in Social and Political Thought. 2nd Edition. Princeton, NJ: Princeton University Press.

Fitzsimmons, Tracy. 2000. Beyond the Barricades: Women, Civil Society, and Participation after Democratization in Latin America. New York: Routledge.

Friedman, Elizabeth J. 2000. Unfinished Transitions: Women and the Gendered Development of Democracy in Venezuela 1936-1996. University Park: The Pennsylvania State University Press.

Funk, Nanette, and Magda Mueller. 1993. Gender Politics and Post-communism: Reflections from Eastern Europe and the Former Soviet Union. New York: Routledge.

Glaurdić, Josip. 2003. "Croatia's Leap toward Political Equality: Rules and Players." In Women's Access to Political Power in Post-Communist Europe, ed. Richard E. Matland and Kathleen A. Montgomery. New York: Oxford University Press, 285-303. 
Inglehart, Ronald, and Pippa Norris. 2003. Rising Tide: Gender Equality and Cultural Change around the World. New York: Cambridge University Press.

Inglehart, Ronald, Pippa Norris, and Christian Welzel. 2002. "Gender Equality and Democracy." Comparative Sociology 1 (3-4): 321-45.

IRI (International Republican Institute). 1999. Public Opinion Survey prepared by Ellen Yount and Nenad Bulat. Unpublished reports.

Irvine, Jill A. 1998. "Public Opinion and the Political Position of Women in Croatia." In Women in the Politics of Post-communist Eastern Europe, ed. Marilyn Rueschemeyer. Armonk, NY, and London: M. E. Sharpe, 215-34.

Jaquette, Jane S. 2001. "Women and Democracy, Regional Differences and Contrasting Views." Journal of Democracy 12 (3): 111-25.

Jaquette, Jane, and Sharon L. Wolchik, eds. 1998. Women and Democracy: Latin America and Central and Eastern Europe. Baltimore: The Johns Hopkins University Press.

Knežević, Djurdja. 1994. “MI nasuprot JA.” Kruh I ruže 1: 14-16.

Knežević, Djurdja, and Kristina Zaborski-Čunović 2000. Izbori u Hrvatskoj 2000, 20\% [ni]je dovolino. Zagreb: Zenska Infoteka.

Lindberg, Steffan I. 2004. "Women's Empowerment and Democratization: The Effects of Electoral Systems, Participation and Experience in Africa." Studies in Comparative International Development 39 (1): 28-53.

Kunovich, Sheri. 2003. "The Representation of Polish and Czech Women in National Politics." Comparative Politics 35 (3): 273-91.

Luciak, Ilja A. 2001. After the Revolution: Gender and Democracy in El Salvador, Nicaragua, and Guatemala. Baltimore: The Johns Hopkins University Press.

Matland, Richard E., and Kathleen A. Montgomery. 2003. Women's Access to Political Power in Post-Communist Europe. New York: Oxford University Press.

Mendelson, Sarah Elizabeth, and John K. Glenn, eds. 2002. The Power and Limits of NGOs: A Critical Look at Building Democracy in Eastern Europe and Eurasia. New York: Columbia University Press.

Moghadam, Valentine. 1995. "Gender and Revolutionary Transformation: Iran 1979 and East Central Europe 1989." Gender \& Society 9 (3): 328-58.

Novosel, Smiljana Leinert. 1999. Žena na pragu 21 stoljeća, izmedju majčinstva i profesije. Zagreb: Ženska grupa ToDa.

O’Donnell, Guillermo. 1996. "Illusions about Consolidation." Journal of Democracy 7 (2): 34-51.

Okeke-Ihejirika, Philomina E., and Susan Franceschet. 2002. "Democratization and State Feminism: Gender Politics in Africa and Latin America." Development and Change $33(3): 439-66$.

Ottoway, Marina, and Theresa Chung. 2002. "Debating Democratic Assistance: Toward a New Paradigm." Problems of Post-Communism 49 (1): 30-41.

Paljković, Morana. 1997. "O ženskim pravima i razini rasprave. Zaposlena žena 24: 1.

Pateman, Carol. 1990. The Disorder of Woman: Democracy, Feminism and Political Theory. Palo Alto, CA: Stanford University Press.

Peto, Andrea, and Judith Szapor. 2004. "Women and the Alternative Public Sphere." NORA 12 (3): 172-81.

Razavi, Shahra. 2001. "Women in Contemporary Democratization." International Journal of Politics, Culture, and Society 15 (1): 201-24.

Richter, James. 2002. "Promoting Civil Society? Democracy Assistance and Russian Women's Organizations.” Problems of Post-Communism 49 (1): 30-41.

Rueschemeyer, Marilyn, ed. 1998. Women in the Politics of Post-communist Eastern Europe. Armonk, NY: M.E. Sharpe.

Seidman, Gary S. 1999. "Gendered Citizenship: South Africa’s Democratic Transition and the Construction of a Gendered State." Gender and Society 13 (3): 287-307. 
Union of Autonomous Trade Unions of Croatia. N.d. “UATUC Women’s Section: Degree of Realization of Women's Trade Union Representation in UATUC.” Unpublished leaflet for union members.

Vincent, Louise. 2001. "A Question of Interest: Women as Opposition.” Democratization 8 (1): 69-84.

Watson, Peggy. 1993. "Eastern Europe’s Silent Revolution: Gender.” Sociology 27 (3): 471-88.

Watson, Peggy. 2000. "Re-thinking Transition: Globalism, Gender and Class." International Feminist Journal of Politics 2 (2): 185-213.

Waylen, Georgina. 2003. "Gender and Transitions: What Do We Know?" Democratization 10 (1): 157-78.

“Žene u predizbornoj kampanji." 2001. Zagreb: B.a.B.e.

“Ženska Seksija SSSH July 7, 1999.” 1999. Unpublished leaflet for union members. 